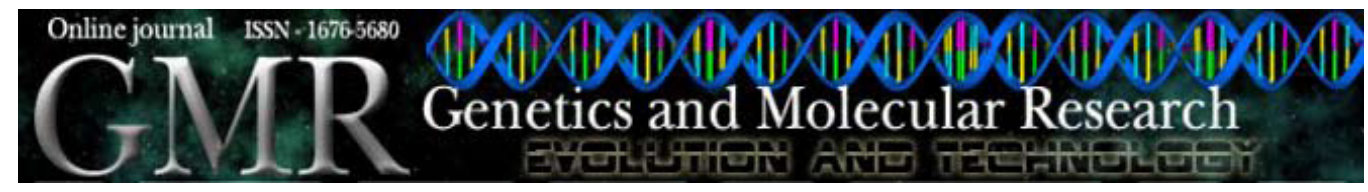

\title{
MRP1 polymorphisms (T2684C, C2007T, C2012T, and C2665T) are not associated with multidrug resistance in leukemic patients
}

\author{
F. Mahjoubi, S. Akbari, M. Montazeri and F. Moshyri \\ Clinical Genetics Department, National Institute of Genetic Engineering and \\ Biotechnology, Tehran, Iran \\ Corresponding author: F. Mahjoubi \\ E-mail: Frouz@nigeb.ac.ir
}

Genet. Mol. Res. 7 (4): 1369-1374 (2008)

Received September 12, 2008

Accepted October 13, 2008

Published December 9, 2008

\begin{abstract}
One of the main problems in treating cancer patients is that cancer cells can develop drug resistance. Resistance to multiple anticancer drugs, so called multidrug resistance (MDR), most likely involves a nonspecific mode of resistance, through drug-efflux transporters. One of the most extensively studied genes involved in MDR is multidrug resistance protein 1 (MRP1). We investigated a possible association between the expression level of MRP1 and the occurrence of MDR in leukemic patients, and we tested the hypothesis that MRP1 polymorphisms are predictive of MDR in patients with acute leukemia. The mRNA level of MRP1 was determined in 111 patients with acute leukemia (including 52 patients with acute myeloid leukemia and 59 patients with acute lymphoblastic leukemia), by quantitative real-time PCR, to determine how it af-
\end{abstract}


fected the response to chemotherapy. We typed T2684C, C2007T, C2012T, and C2665T MRP1 polymorphisms in 111 patients classified as either drug-resistant or drug-responsive. We found that high expression of MRP1 was associated with the MDR phenotype in both acute myeloid leukemia and acute lymphoblastic leukemia patients. There was no effect of a particular genotype on the expression level of the MRPl gene. We found no significant differences in chemosensitivity among any of these genotypes.

Key words: Multidrug resistance protein; Multidrug resistance; Single nucleotide polymorphism

\section{INTRODUCTION}

Drug resistance that develops in cancer cells often results from elevated expression of particular proteins, such as cell membrane transporters. This can result in an increased efflux of cytotoxic drugs from the cancer cells, thus lowering their intracellular concentration (Childs and Ling, 1994).

The human multidrug resistance protein 1 (MRP1) was discovered to induce drug resistance in a drug-selected lung cancer cell. It encodes a 190-kDa polytopic transmembrane protein comprising 1531 amino acids and belongs to subfamily $\mathrm{C}$ of the ATP-binding cassette (ABC)-transporters (Cole et al., 1992; Hipfner et al., 1997; Kuwano et al., 1999). In tumor cells, MRP1 is able to confer resistance against a variety of natural product drugs, such as anthracyclines, vinca alkaloids and VP-16 (Zaman et al., 1993; Cole et al., 1994), and this resistance is associated with a reduced intra-cellular drug accumulation. Furthermore, the overexpression of MRP1 in cancer patients has been reported by many researchers (Kuss et al., 1994; Nooter et al., 1995; Kruh et al., 1995; Norris et al., 1996; Chan et al., 1997; Golalipour et al., 2007, and Mahjoubi F and Akbari S, unpublished data). However, it is not clear why this phenomenon occurs in some patients with the same type of leukemia and not in others.

We have previously shown that neither chromosomal changes nor gene amplification in cancer cells is responsible for increased MRP1 expression (Golalipour et al., 2007).

There have been reports of the influence of some single nucleotide polymorphisms on the structure and expression of the $\mathrm{ABC}$ transporter gene, consequently inducing drug resistance (Siddiqui et al., 2003). Therefore, we aimed to investigate the possible effect of some known MRP1 polymorphisms on MRP1 overexpression in patients with leukemia.

\section{MATERIAL AND METHODS}

All patients were recruited through the same hematology clinic at the two major government hospitals in Tehran.

After obtaining informed consent, we collected peripheral blood from 111 patients 
with acute myelogenous leukemia (AML) or acute lymphoblastic leukemia (ALL). Patients were divided into three groups: in complete remission (CR), in relapse and sensitive to drug (RS), and in relapse and resistant to drug (RR). Patients were considered to be in the complete remission group if established criteria were met, which included cellular marrow with $<5 \%$ blast cells, neurophil count $>1.5 \times 10^{9} / \mathrm{L}$, platelet count $\geq 100 \times 10^{9} / \mathrm{L}$, and no evidence of leukemia in other sites, observed over six months. Finally, the relapsed group consisted of patients with relapse within 6 months after remission. The resistant HL-60 cell line known to overexpress $M R P 1$ and peripheral blood of 30 healthy individuals were used as overexpressed and normal controls, respectively.

\section{Total RNA isolation and cDNA synthesis}

RNA extraction and cDNA synthesis were performed as previously described (Golalipour et al., 2007).

\section{Real-time RT-PCR}

The sequences of primers for assessment of MRPI expression were: forward 5'-CGGAAACCATCCACGACCCTAATC-3' and reverse 5'-ACCTCCTCATTCGCATCC ACCTGG-3'. The sequences of primers used for assessment of $\beta$-2-microglobulin expression were forward 5'-CTATCCAGCGTACTCCAAAG-3' and reverse 5'-GACAAGTCTGAATG CTCCAC-3'. For quantification of gene expression, we used the Lightcycler ${ }^{\mathrm{TM}}$ system (Roche Applied Sciences) and the Fast-Start DNA Master SYBR-Green I kit (Roche Applied Sciences). A standard Lightcycler polymerase chain reaction (PCR) program was established for each gene. Standard curves were generated using logarithmic regression. Thermal cycling consisted of an initial denaturation step at $95^{\circ} \mathrm{C}$ for $10 \mathrm{~min}$ followed by a 3 -step (primer annealing, amplification and quantification) program repeated for 50 cycles with temperature ramp rate of $20^{\circ} \mathrm{C} / \mathrm{s}$. The program was $95^{\circ} \mathrm{C}$ for $0 \mathrm{~s}, 64^{\circ} \mathrm{C}$ for $10 \mathrm{~s}$ and $72^{\circ} \mathrm{C}$ for $40 \mathrm{~s}$ with a single fluorescence acquisition at the end of the elongation step. The third segment consisted of a melting curve program at $95^{\circ} \mathrm{C}$ for $0 \mathrm{~s}, 72^{\circ} \mathrm{C}$ for $10 \mathrm{~s}$ and $95^{\circ} \mathrm{C}$ for $0 \mathrm{~s}$ with a linear temperature transition rate of $0.1^{\circ} \mathrm{C} / \mathrm{s}$ with continuous fluorescence acquisition. Finally, a cooling program cooled the reaction mixture to $40^{\circ} \mathrm{C}$. The $\beta$-2-microglobulin PCR program was the same except that the annealing temperature in the second segment was $50^{\circ} \mathrm{C}$ for $10 \mathrm{~s}$. To ascertain that fluorescence signals were associated with specific products, $1.5 \%$ agarose gel electrophoresis was performed to check for the absence of nonspecific bands.

An external standard curve for $M R P 1$ and $\beta$-2-microglobulin was generated from serial dilution of mRNA of each gene. The standard curve was constructed from the plot of crossing points against the copy number of serially diluted standard samples. For each sample, the amounts of MRP1 and the housekeeping gene were measured. Finally, the relative copy number was calculated by the ratio of $M R P 1$ to $\beta$-2-microglobulin copy number in each sample.

Statistical calculations and tests were performed using the SPSS 13.0 software (SPSS, Inc., Chicago, USA). Normality of data was tested using the Shapiro-Wilk normality test. Differences between groups were analyzed by one-way ANOVA and the limit of statistical significance was defined as $\mathrm{P}<0.05$. 


\section{DNA extraction and PCR}

Genomic DNA was isolated from enriched peripheral blood blasts of patients using the Nucleose DNA Prep kit (Stratagene, La Jolla, USA) and TRI-ZOL reagent (Gibco BRL, Gaithersburg, USA), respectively. Pelleted DNA was resuspended in extragene E solution.

The primer pairs used to amplify genomic DNA were designed based on the genomic sequence of MRP1 reported in GenBank. PCR was performed using the thermal profile described below. The standard PCR was carried out in a $25-\mu \mathrm{L}$ volume containing $200 \mathrm{ng}$ genomic DNA. PCR was performed using the primers below:

For exon 16, forward primer was 5'-CAGGTGTGTTGTGTGTCGTTTC-3' and reverse primer was 5'-TCTGGCACAGGGACAGTC-3'.

For exon 20, forward primer was 5'-GCATCTGCCTCATATAACCC-3' and reverse primer was 5'-GGCAGGGTCCTTAGGTTG-3'.

The PCR mixture included $1 \mu \mathrm{M}$ primer, $200 \mu \mathrm{M}$ of each dNTP (Sigma), Taq DNA polymerase $1 \mathrm{X}$ buffer with $1.5 \mathrm{mM} \mathrm{MgCl}$, and 2.5 units Taq polymerase ( $5 \mathrm{U} / \mu \mathrm{L}$, Sigma).

The PCR program was as follows for exons 16 and 20: The initial denaturation step at $94^{\circ} \mathrm{C}$ for $5 \mathrm{~min}$, followed by the amplification program 30 cycles of: $94^{\circ} \mathrm{C}$ for $30 \mathrm{~s} ; 52^{\circ} \mathrm{C}$ for $35 \mathrm{~s}$, and $72^{\circ} \mathrm{C}$ for $35 \mathrm{~s}$, followed by one cycle of $72^{\circ} \mathrm{C}$ for $10 \mathrm{~min}$.

The PCR products were used for single-strand conformation polymorphism (SSCP) and/or sequencing, using an automated sequencer (moel377, ABI).

\section{RESULTS}

\section{mRNA expression of MRP1 in CR compared to RS and RR groups}

A statistically significant $(\mathrm{P}<0.05)$ difference between $M R P 1$ expression level between CR and RS/RR groups was observed in both AML and ALL patients. Mean expression in the CR group $(0.032 \pm 0.031$ in AML, and $0.3104 \pm 0.4791$ in ALL patients $)$ was significantly lower than mean expression in the RS $(0.422 \pm 0.297$ in AML and $0.55 \pm 0.1638$ in ALL patients) and RR $(0.619 \pm 0.284$ in AML and $0.7598 \pm 0.21$ in ALL patients) groups (Table 1 and Figure 1).

\begin{tabular}{|c|c|c|}
\hline Groups & Patients $(\mathrm{N}=111)$ & $M R P 1$ expression level \\
\hline $\mathrm{CR}$ & 53 & $1.00 \mathrm{E}^{-11}-1.00 \mathrm{E}^{-02}$ \\
\hline RS & 34 & $1.00 \mathrm{E}^{-10}-1.00 \mathrm{E}^{+05}$ \\
\hline $\mathrm{RR}$ & 24 & $1.00 \mathrm{E}^{-01}-1.00 \mathrm{E}^{+16}$ \\
\hline
\end{tabular}

\section{Genotyping at MRP1 2684, 2007, 2012, and 2665}

To evaluate $M R P 1$ involvement in drug resistance in leukemia patients and to explore its pharmacogenomics, we typed the 4 polymorphisms in 111 patients classified as either drugresistant or drug-responsive. 


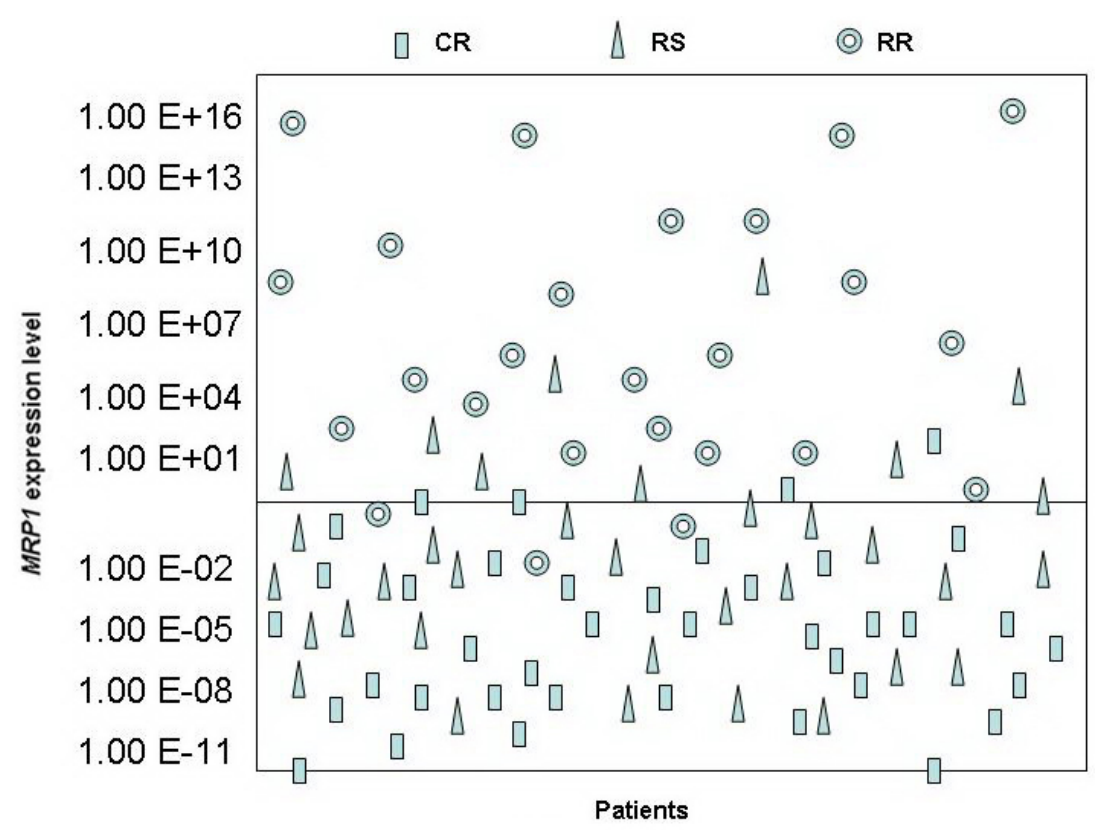

Figure 1. Expression of MRP1 mRNA in peripheral blood of patients. Each symbol represents one patient. $\mathrm{CR}=$ complete remission; $\mathrm{RS}=$ relapse and sensitive to drug; $\mathrm{RR}=$ relapse and resistant to drug.

In order to identify genetic variations, PCR-SSCP analysis of all fragments was carried out with DNA isolated from blood of 111 patients. Since there was no fragment variations by SSCP among any of these patients, PCR products were sequenced, and comparison was made with the published MRP1 sequences. GenBank accession numbers AC003026 and U91318, which included the complete genomic sequence of exon 12 to exon 31, were used as wild-type sequences. The sequences were analyzed with the use of the Sequencer Navigator program. The sequencing procedure resulted in the identification of no mutation.

\section{DISCUSSION}

MRP1 gene is an important candidate gene potentially influencing the response to anticancer drugs (Chan et al., 1997; Golalipour et al., 2007). We have previously shown that in a group of AML patients, overexpression of $M R P 1$ seemed to contribute to the multidrug resistance phenotype (Golalipour et al., 2007, and Mahjoubi F and Akbari S, unpublished data). Comparing MRP1 gene copy number in all those patients with a high level of MRP1 mRNA with normal healthy individuals, no sign of gene amplification could be seen in any of those cases (Golalipour et al., 2007). Since mutations affecting MRP1 expression and/ or MRP1 transport activity can be expected to influence the pharmacokinetic properties of chemotherapeutic drugs and consequently their desired and adverse effects, we attempted to examine whether the genotype of $M R P 1$ correlates with the expression status. 
In this study enrolling a larger number of patients, we were able to confirm that the MRP1 gene could be responsible for inducing drug resistance in both AML and ALL patients. However, our data suggest that none of the common MRP1 polymorphisms (T2684C, C2007T, $\mathrm{C} 2012 \mathrm{~T}$, and $\mathrm{C} 2665 \mathrm{~T}$ ) are associated with multidrug resistance in these groups of patients.

In conclusion, we presented evidence based on quantitative real-time PCR that upregulation of $M R P 1$ gene may induce multidrug resistance in leukemic patients, but none of the known polymorphisms seemed to have effect on the expression level of this gene in our patient group. It should be noted that patients with drug resistance and drug sensitive leukemia selected for this study were seen at only two referral centers and thus may not represent the whole Iranian population.

In the future, an investigation with a larger number of cases should be addressed.

\section{ACKNOWLEDGMENTS}

Research supported by NIGEB, grant No. 283.

\section{REFERENCES}

Chan HS, Lu Y, Grogan TM, Haddad G, et al. (1997). Multidrug resistance protein (MRP) expression in retinoblastoma correlates with the rare failure of chemotherapy despite cyclosporine for reversal of P-glycoprotein. Cancer Res. 57: 2325-2330.

Childs S and Ling V (1994). The MDR superfamily of genes and its biological implications. Important Adv. Oncol. 21-36.

Cole SP, Bhardwaj G, Gerlach JH, Mackie JE, et al. (1992). Overexpression of a transporter gene in a multidrug-resistant human lung cancer cell line. Science 258: 1650-1654.

Cole SP, Sparks KE, Fraser K, Loe DW, et al. (1994). Pharmacological characterization of multidrug resistant MRPtransfected human tumor cells. Cancer Res. 54: 5902-5910.

Golalipour M, Mahjoubi F, Sanati MH and Alimoghaddam K (2007). Gene dosage is not responsible for the upregulation of MRP1 gene expression in adult leukemia patients. Arch. Med. Res. 38: 297-304.

Hipfner DR, Almquist KC, Leslie EM, Gerlach JH, et al. (1997). Membrane topology of the multidrug resistance protein (MRP). A study of glycosylation-site mutants reveals an extracytosolic NH2 terminus. J. Biol. Chem. 272: 23623-23630.

Kruh GD, Gaughan KT, Godwin A and Chan A (1995). Expression pattern of MRP in human tissues and adult solid tumor cell lines. J. Natl. Cancer Inst. 87: 1256-1258.

Kuss BJ, Deeley RG, Cole SP, Willman CL, et al. (1994). Deletion of gene for multidrug resistance in acute myeloid leukaemia with inversion in chromosome 16: prognostic implications. Lancet 343: 1531-1534.

Kuwano M, Toh S, Uchiumi T, Takano H, et al. (1999). Multidrug resistance-associated protein subfamily transporters and drug resistance. Anticancer Drug Des. 14: 123-131.

Nooter K, Westerman AM, Flens MJ, Zaman GJ, et al. (1995). Expression of the multidrug resistance-associated protein (MRP) gene in human cancers. Clin. Cancer Res. 1: 1301-1310.

Norris MD, Bordow SB, Marshall GM, Haber PS, et al. (1996). Expression of the gene for multidrug-resistance-associated protein and outcome in patients with neuroblastoma. N. Engl. J. Med. 334: 231-238.

Siddiqui A, Kerb R, Weale ME, Brinkmann U, et al. (2003). Association of multidrug resistance in epilepsy with a polymorphism in the drug-transporter gene ABCB1. N. Engl. J. Med. 348: 1442-1448.

Zaman GJ, Versantvoort CH, Smit JJ, Eijdems EW, et al. (1993). Analysis of the expression of MRP, the gene for a new putative transmembrane drug transporter, in human multidrug resistant lung cancer cell lines. Cancer Res. 53: 1747-1750. 